\title{
JPEB
}

Jurnal Penelitian Ekonomi dan Bisnis, 4 (1), 2019, Hal: 38 - 51

http://www.jpeb.dinus.ac.id

\section{INTENSI KEWIRAUSAHAAN MAHASISWA (STUDI PERBANDINGAN ANTARA MAHASISWA PTS DAN PTN)}

\author{
Tri Harsini Wahyuningsih* \\ Sekolah Tinggi Ilmu Manajemen, YKPN Yogyakarta \\ Jalan Palagan Tentara Pelajar KM.7, Yogyakarta, Indonesia \\ *Corresponding Author: triharsiniw@gmail.com
}

Diterima: Desember 2018 ; Direvisi: Januari 2019 ; Dipublikasikan: Maret 2019

\begin{abstract}
This study aims to analyze the factors that encourage student entrepreneurial intentions, by comparing students who study in private universities (PTS) and state universities (PTN). Sampling with incidental sampling. After obtaining data by distributing questionnaires, then processing it, it was found that the need for achievement did not affect student entrepreneurial intentions, while self-efficacy had a positive effect on student entrepreneurial intentions, both for students studying at PTS and PTN. Self-efficacy is proven to be the most dominant factor influencing entrepreneurial intentions of students in both types of universities (PT). Instrumentation readiness has a positive effect on entrepreneurial intentions of PTN students, but does not affect PTS students. Without distinguishing the origin of PT, the need for achievement also does not affect the entrepreneurial intentions of students, while self-efficacy and readiness of instrumentation have a positive effect on student entrepreneurial intentions. Based on demographic conditions, the differences in findings between PTS and PTN students only on gender and age factors. For PTS, male and older students have higher entrepreneurial intentions, while those for PTN are the opposite. Meanwhile, students with economic education, work experience, and entrepreneurial parents have a higher entrepreneurial intention, both for PTS and PTN students.
\end{abstract}

Keywords: Entrepreneurial Intentions; The Need For Achievement; Self-Efficacy; Readiness For Instrumentation

\begin{abstract}
ABSTRAK
Penelitian ini bertujuan untuk menganalisis faktor-faktor yang mendorong intensi kewirausahaan mahasiswa, dengan membandingkan antara mahasiswa yang kuliah di perguruan tinggi swasta (PTS) dan perguruan tinggi negeri (PTN). Pengambilan sampel dengan insidental sampling. Setelah memperoleh data dengan menyebarkan kuesioner, kemudian mengolahnya, diketemukan bahwa kebutuhan akan prestasi tidak berpengaruh terhadap intensi kewirausahaan mahasiswa, sedangkan efikasi diri berpengaruh positif terhadap intensi kewirausahaan mahasiswa, baik untuk mahasiswa yang kuliah di PTS maupun PTN. Efikasi diri terbukti sebagai faktor yang paling dominan mempengaruhi intensi kewirausahaan mahasiswa di kedua jenis perguruan tinggi (PT) tersebut. Kesiapan instrumentasi berpengaruh positif terhadap intensi kewirausahaan mahasiswa PTN, namun tidak berpengaruh bagi mahasiswa PTS. Tanpa membedakan asal PT, kebutuhan akan prestasi juga tidak berpengaruh terhadap intensi kewirausahaan mahasiswa, sedangkan efikasi diri dan kesiapan instrumentasi berpengaruh positif terhadap intensi kewirausahaan mahasiswa. Berdasarkan kondisi demografis, perbedaan temuan antara mahasiswa PTS dan PTN hanya pada faktor jenis kelamin dan usia. Untuk PTS, mahasiswa laki-laki dan berusia tua memiliki intensi kewirausahaan yang lebih tinggi, sedangkan untuk PTN sebaliknya. Sementara itu, mahasiswa yang berlatarbelakang pendidikan ekonomi, berpengalaman kerja, dan orangtuanya wirausaha memiliki intensi kewirausahaan lebih tinggi, baik untuk mahasiswa PTS maupun PTN.
\end{abstract}

Kata Kunci: Intensi Kewirausahaan; Kebutuhan Akan Prestasi; Efikasi Diri; Kesiapan Instrumentasi 


\section{PENDAHULUAN}

Pengangguran masih merupakan persoalan ketenagakerjaan yang cukup serius di Indonesia. Badan Pusat Statistik (BPS) melansir bahwa jumlah penganggur pada bulan Agustus 2015 mengalami peningkatan sebanyak 110.000 orang dibanding bulan Februari 2015 dan 320.000 orang jika dibanding bulan Agustus 2014. Sementara itu, tingkat pengangguran terbuka jenjang pendidikan tinggi mengalami peningkatan juga. Pengangguran berpendidikan diploma meningkat dari 6,14\% pada bulan Agustus 2014 menjadi sebesar 7,54\% pada bulan Agustus 2015, sedangkan untuk tingkat universitas mengalami peningkatan dari 5,65\% pada Agustus 2014 menjadi 6,40\% pada Agustus 2015 (https://www.bps.go.id/index.php/Brs.). Berdasar data tersebut diketahui bahwa jumlah penganggur berpendidikan tinggi masih mengalami kenaikan walaupun tidak menunjukkan jumlah yang signifikan dibandingkan peningkatan jumlah penganggur untuk angkatan kerja berpendidikan menengah.

Salah satu tujuan pendidikan tinggi yang tercantum dalam Undang-Undang Republik Indonesia nomor 12 tahun 2012 adalah mengembangkan potensi mahasiswa agar menjadi manusia yang beriman dan bertakwa kepada Tuhan Yang Maha Esa dan berakhlak mulia, sehat, berilmu, cakap, kreatif, mandiri, terampil, kompeten, dan berbudaya untuk kepentingan bangsa. Untuk mewujudkan tujuan tersebut, Direktur Jenderal Pendidikan tinggi, Djoko Santoso, dalam prakata modul pembelajaran kewirausahaan menyatakan bahwa mata kuliah dasar umum (MKDU) di perguruan tinggi ditambah dengan bahasa inggris, kewirausahaan, dan mata kuliah yang mendorong pada pengembangan karakter lainnya, baik yang terintegrasi maupun individu. Mata kuliah kewirausahaan merupakan pelajaran yang membentuk karakter wirausaha atau minimal menambah pengetahuan mahasiswa tentang seluk-beluk bisnis, baik dari sisi soft skill maupun hard skill, sehingga mampu memanfaatkan peluang yang ada di sekitarnya dalam menciptakan usaha sendiri setelah lulus maupun saat masih kuliah. Dengan demikian, pemberlakuan mata kuliah kewirausahaan di perguruan tinggi diharapkan dapat mengurangi jumlah penganggur di Indonesia.

Pemberlakuan mata kuliah kewirausahaan, dengan berbagai nama yang berbeda-beda di setiap perguruan tinggi, setidaknya memberikan gambaran kepada mahasiswa bahwa ada peluang untuk melakukan hal lain yang lebih baik selain mencari pekerjaan setelah lulus nantinya. Saat ini jumlah pengusaha di Indonesia hanya sekitar $1,65 \%$ dari jumlah penduduk (menteri koperasi dan UKM, 12 Maret 2015), padahal sebuah negara bisa berkembang bila jumlah pengusahanya minimal $2 \%$ dari jumlah penduduk negara tersebut. Peluang menjadi wirausaha di Indonesia masih sangat besar, apalagi bila dibandingkan dengan peluang pasar yang tersedia. Dalam mata kuliah Kewirausahaan, mahasiswa juga dimotivasi untuk menjadi wirausaha yang nantinya tidak hanya bermanfaat bagi dirinya sendiri, tetapi juga memberikan manfaat bagi orang lain dengan membuka lapangan pekerjaan. Mahasiswa 'dipaksa' untuk melakukan praktek bisnis dalam proses pembelajaran di mata kuliah tersebut sehingga mahasiswa dapat benar-benar merasakan bagaimana berprofesi sebagai wirausaha itu.

Beberapa perguruan tinggi juga menyelenggarakan kompetisi business plan untuk mendorong mahasiswanya merealisir impiannya menjadi wirausaha, dengan memberikan hadiah sejumlah modal tertentu yang disertai dengan pendampingan usaha nantinya kepada pemenangnya. Kompetisi kewirausahaan saat ini semakin banyak diselenggarakan, seperti CMA (Citi Microentrepreneurship Award), WMM (wirausaha muda mandiri), PKM-K (program kreativitas mahasiswa bidang kewirausahaan), dan masih banyak lagi lainnya. Semua cara tersebut pada dasarnya digunakan untuk mendorong masyarakat, khususnya mahasiswa, menjadi seorang wirausaha yang nantinya dapat menciptakan lapangan pekerjaan.

Namun demikian, benarkah semua cara itu dapat mendorong minat mahasiswa untuk menjadi seorang wirausaha ? Penelitian tentang faktor-faktor yang mempengaruhi intensi kewirausahaan mahasiswa telah banyak dilakukan, diantaranya oleh Indarti (2008), 
Sudarusman (2011), Sarwoko (2011), Sata (2013), Endratno (2014), Herawati (2015), dan Vilathuvahna (2015). Subyek penelitian tersebut adalah mahasiswa dari satu sampai dengan tiga perguruan tinggi saja, sehingga dalam kesempatan ini peneliti akan melakukan perbandingan antara mahasiswa yang kuliah di perguruan tinggi swasta (PTS) dan perguruan tinggi negeri (PTN), yang belum dilakukan oleh peneliti lain khususnya di wilayah Daerah Istimewa Yogyakarta.

Penelitian ini menggabungkan tiga pendekatan untuk melihat faktor-faktor penentu intensi kewirausahaan, seperti yang dilakukan oleh Indarti (2008), dengan menambahkan latar belakang keluarga/orangtua. Adapun ketiga faktor tersebut adalah 1) faktor kepribadian: kebutuhan akan prestasi dan efikasi diri, 2) faktor lingkungan, yang dilihat pada tiga elemen kontekstual: akses kepada modal, informasi, dan jaringan sosial, serta 3) faktor demografis: jenis kelamin, usia, latar belakang pendidikan, pengalaman bekerja, dan latar belakang keluarga/orangtua. Ketiga faktor tersebut diduga berpengaruh positif dan signifikan terhadap intensi kewirausahaan mahasiswa.

Artikel yang didasarkan pada hasil penelitian ini bertujuan untuk menganalisis 1) pengaruh kebutuhan akan prestasi terhadap intensi kewirausahaan mahasiswa, 2) pengaruh efikasi diri terhadap intensi kewirausahaan mahasiswa, 3) pengaruh kesiapan instrumentasi terhadap intensi kewirausahaan mahasiswa, 4) pengaruh jender terhadap intensi kewirausahaan mahasiswa, 5) pengaruh usia terhadap intensi kewirausahaan mahasiswa, 6) pengaruh latarbelakang pendidikan terhadap intensi kewirausahaan mahasiswa, 7) pengaruh pengalaman kerja terhadap intensi kewirausahaan mahasiswa, dan 8) pengaruh latarbelakang orangtua terhadap intensi kewirausahaan mahasiswa. Dengan mengetahui faktor-faktor pendorong intensi kewirausahaan mahasiswa maka pihak perguruan tinggi dapat memberikan tekanan pada materi pembelajaran yang dirasa kurang untuk mendukung minat berwirausaha mahasiswa. Berbagai upaya dan pendekatan dapat dirangkai dalam sebuah program untuk meningkatkan intensi kewirausahaan mahasiswa sehingga pendidikan kewirausahaan tidak hanya sekedar menjadi mata kuliah saja. Kemungkinan terjadinya perbedaan hasil analisis untuk mahasiswa PTS dan PTN dapat digunakan untuk saling mengevaluasi yang akhirnya bisa bermanfaat bagi keberhasilan pendidikan kewirausahaan pada masing-masing perguruan tinggi tersebut.

\section{TINJAUAN PUSTAKA}

\section{Pengertian Kewirausahaan dan Intensi Kewirausahaan}

Kewirausahaan (entrepreneurship) adalah kemampuan kreatif dan inovatif yang dijadikan dasar, kiat, dan sumberdaya untuk mencari peluang menuju sukses (Suryana, 2006). Kreativitas dan inovasi menjadi kunci untuk mencapai kesuksesan. Kreativitas diartikan sebagai kemampuan mengembangkan ide dan cara-cara baru dalam memecahkan masalah dan menemukan peluang, sedangkan inovasi merupakan kemampuan menerapkan kreativitas dalam rangka memecahkan masalah dan menemukan peluang.

Untuk dapat menemukan peluang, seseorang harus memiliki pengetahuan, kemampuan, dan kemauan. Ada kemauan tetapi tidak memiliki kemampuan dan pengetahuan tidak akan membuat seseorang menjadi wirausaha yang sukses. Sebaliknya, memiliki pengetahuan dan kemampuan tetapi tidak disertai kemauan tidak akan membuat wirausaha mencapai kesuksesan. Pengetahuan, kemampuan, dan kemauan harus diintegrasikan untuk mencapai kesuksesan dalam berwirausaha.

Kecenderungan dan keinginan seseorang untuk menjadi wirausahawan didefinisikan sebagai intensi berwirausaha (Sata, 2013). Intensi berwirausaha ini identik dengan kemauan seseorang. Pengetahuan dan kemampuan saja tidaklah cukup untuk menjadikan seseorang sebagai wirausaha, namun diperlukan juga adanya intensi kewirausahaan yang tinggi. Faktor- 
faktor yang mendorong intensi berwirausaha seseorang perlulah dipertimbangkan sebagai upaya untuk memotivasi seseorang menjadi wirausaha yang sukses.

\section{Faktor Pendorong Intensi Kewirausahaan}

Penelitian seputar intensi kewirausahaan menggunakan tiga pendekatan untuk melihat faktor-faktor yang mendorong intensitas tersebut (Indarti, 2008). Ketiga pendekatan tersebut meliputi karakteristik kepribadian, karakteristik lingkungan, dan karakteristik demografis.

Karakteristik kepribadian terdiri dari kebutuhan akan prestasi dan efikasi diri. Suryana (2006) menyebutkan bahwa kebutuhan berprestasi wirausaha terlihat dalam bentuk tindakan untuk melakukan sesuatu yang lebih baik dan efisien dibanding sebelumnya. Namun demikian, kebutuhan berprestasi tidak terbukti sebagai prediktor intensi kewirausahaan (Indarti, 2008; Sarwoko, 2011; Vilathuvahna, 2015), sedangkan Sudarusman (2011) dan Herawati (2015) menemukan bahwa kebutuhan berprestasi merupakan faktor pendorong intensi kewirausahaan mahasiswa. Efikasi diri adalah keyakinan individu atas kemampuannya untuk menyelesaikan suatu tugas. Variabel ini terbukti mempengaruhi intensi kewirausahaan mahasiswa (Indarti, 2008; Sudarusman, 2011; Sarwoko, 2011; Endratno, 2014; Herawati, 2015; Vilathuvahna, 2015).

Karakteristik lingkungan dapat dilihat pada tiga elemen kontekstual yang meliputi akses kepada modal, informasi, dan jaringan sosial. Ketiga elemen ini jelas berpengaruh terhadap intensitas kewirausahaan. Dalam bisnis, pasti dibutuhkan modal finansial, walaupun keperolehannya bisa didapatkan dari bekerjasama dengan pihak lain. Ketersediaan informasi dan jaringan sosial tidak kalah pentingnya dipertimbangkan seseorang untuk memulai usaha.

Karakteristik demografis yang meliputi jenis kelamin, umur, latarbelakang pendidikan, pengalaman bekerja, dan latar belakang orangtua menjadi variabel yang diprediksi mempengaruhi intensi kewirausahaan mahasiswa. Walaupun temuan dari beberapa peneliti tidak mendukung hipotesis tersebut.

\section{Hipotesis Penelitian}

Berdasarkan latarbelakang permasalahan yang telah diuraikan dalam bagian pendahuluan, telaah pustaka, dan penelitian sebelumnya maka dapat dirumuskan hipotesis sebagai berikut:

$\mathrm{H}_{1}$ : Kebutuhan akan prestasi berpengaruh positif terhadap intensi kewirausahaan mahasiswa.

$\mathrm{H}_{2}$ : Efikasi diri berpengaruh positif terhadap intensi kewirausahaan mahasiswa.

$\mathrm{H}_{3}$ : Kesiapan instrumentasi berpengaruh positif terhadap intensi kewirausahaan mahasiswa.

$\mathrm{H}_{4}$ : Laki-laki memiliki intensi kewirausahaan lebih tinggi daripada perempuan.

$\mathrm{H}_{5}$ : Mahasiswa yang berusia muda memiliki intensi kewirausahaan lebih tinggi daripada mahasiswa berusia tua.

$\mathrm{H}_{6}$ : Mahasiswa yang berlatarbelakang pendidikan ekonomi dan bisnis memiliki intensi kewirausahaan lebih tinggi daripada mahasiswa yang berlatarbelakang pendidikan non-ekonomi dan bisnis.

$\mathrm{H}_{7}$ : Mahasiswa yang mempunyai pengalaman kerja memiliki intensi kewirausahaan lebih tinggi daripada mahasiswa yang tidak mempunyai pengalaman kerja.

$\mathrm{H}_{8} \quad$ : Mahasiswa yang orangtuanya pebisnis memiliki intensi kewirausahaan lebih tinggi daripada mahasiswa yang orangtuanya bukan pebisnis. 
Tri Harsini Wahyuningsih : Intensi Kewirausahaan Mahasiswa (Studi Perbandingan Antara Mahasiswa PTS Dan PTN)

\section{METODE PENELITIAN}

Oleh karena penelitian ini bertolak dari suatu hipotesis yang diperoleh dari suatu teori tertentu maka penelitian ini termasuk dalam explanatory research, dengan maksud untuk membenarkan atau memperkuat hipotesis tersebut (Wiyono, 2011). Penelitian ini menggunakan data primer yang diperoleh secara langsung dari responden, meliputi data yang digunakan untuk mengukur variabel independen dan variabel dependen. Variabel independen meliputi kebutuhan akan prestasi, efikasi diri, dan kesiapan instrumentasi; sedangkan variabel dependennya adalah intensi kewirausahaan mahasiswa. Data untuk karakteristik demografis yang meliputi jenis kelamin, umur, latarbelakang pendidikan, pengalaman bekerja, dan latar belakang orangtua juga dicantumkan dalam kuesioner yang diberikan kepada mahasiswa yang kuliah di perguruan tinggi swasta (PTS) dan perguruan tinggi negeri (PTN) wilayah Yogyakarta.

Populasi penelitian ini adalah seluruh mahasiswa yang kuliah di perguruan tinggi swasta dan negeri di Daerah Istimewa Yogyakarta. Oleh karena keterbatasan waktu yang dimiliki oleh peneliti maka penelitian ini hanya akan mengambil sampel dari sebagian populasi yang ada. Pengambilan sampel didasarkan pada insidental sampling, yaitu sampel yang diambil dari siapa saja yang kebetulan ada di lokasi penelitian yang telah ditetapkan. Data yang diterbitkan oleh BPS dalam D.I. Yogyakarta Dalam Angka 2014 (www.bappeda.jogjaprov.go.id.) menyebutkan bahwa saat penelitian ini terdapat 10 PTN dengan jumlah mahasiswa 110.437 orang dan 107 PTS dengan jumlah mahasiswa sebanyak 74.165 orang. Dengan demikian total populasi dalam penelitian ini adalah 184.602 orang mahasiswa. Berdasarkan rumus Slovin yang diperoleh dari Wiyono (2011), dengan tingkat kepercayaan sebesar 95\% didapatkan sampel sebanyak 400 responden, dimana jumlah ini ditetapkan peneliti sebagai jumlah minimal sampel dalam penelitian ini.

Setelah kuesioner diisi oleh responden maka dilakukan uji instrumen (validitas dan reliabilitas), uji asumsi dasar (normalitas), uji asumsi klasik (multikolinearitas dan heteroskedastisitas), dan uji hipotesis. Untuk mengetahui arah hubungan antara variabel independen dan dependen digunakan uji regresi linier berganda, sedangkan untuk mengetahui ada tidaknya pengaruh dua variabel tersebut secara parsial digunakan uji $t$ dengan $\alpha=0.05$. Koefisien determinasi $\left(\mathrm{R}^{2}\right)$ digunakan untuk mengukur seberapa jauh kemampuan model dalam menerangkan variasi variabel dependen. Untuk membandingkan rata-rata dua populasi atau lebih, digunakan analisis Compare means (Wijaya, 2012). Oleh karena dalam penelitian ini juga menguji ada tidaknya perbedaan mean antar dua kelompok yang saling independen secara signifikan, maka digunakan Independent Samples T test.

\section{HASIL DAN PEMBAHASAN Karakteristik Responden}

Hasil dari pendistribusian kuesioner sebanyak 450 eksemplar diperoleh 429 kuesioner yang dapat digunakan dalam penelitian ini, berasal dari 175 mahasiswa PTS dan 254 mahasiswa PTN. Jumlah sampel ini telah proporsional dengan jumlah populasi sebesar 184.602 mahasiswa, yang terdiri dari 74.165 mahasiswa PTS (40\%) dan 110.437 mahasiswa PTN (60\%). Karakteristik responden dirangkum dalam Tabel 1 dibawah ini. 
Tabel 1. Karakteristik Responden

\begin{tabular}{lllll}
\hline \multirow{2}{*}{ KARAKTERISTIK } & \multicolumn{2}{l}{ PTS $(\mathrm{n}=175)$} & \multicolumn{2}{l}{ PTN $(\mathrm{n}=254)$} \\
\cline { 2 - 5 } & $\mathrm{n}$ & $\%$ & $\mathrm{n}$ & $\%$ \\
\hline Jenis Kelamin: & & & & \\
- Laki-laki & 89 & 50,9 & 99 & 39,0 \\
- Perempuan & 86 & 49,1 & 155 & 61,0 \\
\hline Usia: & & & & \\
- kurang dari 20 tahun & 106 & 60,6 & 135 & 53,1 \\
- 20 tahun keatas & 69 & 39,4 & 119 & 46,9 \\
\hline latarbelakang pendidikan: & & & & \\
- Ekonomi & 113 & 64,6 & 25 & 9,8 \\
- Non ekonomi & 62 & 35,4 & 229 & 90,2 \\
\hline Pengalaman Kerja: & & & & \\
- Pernah bekerja & 54 & 30,9 & 77 & 30,3 \\
- Tidak pernah bekerja & 121 & 69,1 & 177 & 69,7 \\
\hline Latarbelakang orangtua: & \multicolumn{4}{l}{} \\
- Wirausaha & 68 & 38,9 & 80 & 31,5 \\
- Non wirausaha & 107 & 61,1 & 174 & 68,5 \\
\hline
\end{tabular}

\section{Uji Validitas dan Reliabilitas}

Uji validitas dan reliabilitas dilakukan pada instrumen penelitian dari kuesioner yang telah diisi oleh responden. Uji validitas dilakukan dengan membandingkan antara $r$ hitung dan $r$ tabel melalui software SPSS. Instrumen dikatakan valid bila $r$ hitung $>r$ tabel. Dengan jumlah sampel penelitian (n) sebanyak 429 responden maka besarnya df $=429-2=427$ sehingga didapat $\mathrm{r}$ tabel $=0,095$ pada signifikansi 5\% (2-tailed). $\mathrm{r}$ hitung dilihat dari Corrected Item-Total Correlation yang dihasilkan dari uji masing-masing variabel. Adapun pengujian reliabilitas dilihat dari nilai Cronbach's Alpha yang dihasilkan dengan menggunakan software yang sama. Instrumen dikatakan reliabel bila nilai Cronbach's Alpha $>0,60$ (Hair, et al., 2010).

Hasil uji validitas untuk semua variabel menunjukkan bahwa ada satu instrumen yang tidak valid, karena nilai Corrected Item-Total Correlation lebih kecil dari 0,095 sehingga instrumen intensi_2 tidak dapat diolah untuk melakukan analisis data. Dengan demikian variabel intensi kewirausahaan hanya tinggal 2 instrumen saja. Sedangkan hasil uji reliabilitas untuk semua variabel menunjukkan bahwa semua variabel yang digunakan dalam penelitian ini reliabel, karena nilai Cronbach's Alpha $>0,6$.

\section{Uji Asumsi Klasik}

Uji multikolinearitas bertujuan untuk menguji apakah model regresi ditemukan adanya korelasi antar variabel independen. Model regresi yang baik seharusnya tidak terjadi korelasi di antara variabel independen (Ghozali, 2013). Dalam penelitian ini digunakan matriks korelasi antar variabel independen dan perhitungan nilai tolerance dan VIF (Variance Inflation Factor). Apabila nilai VIF melebihi angka 10 berarti ada multikolinearitas antar variabel independen dalam model regresi. Hasil uji multikolinearitas menunjukkan bahwa tidak ada multikolinearitas antar variabel independen dalam penelitian ini, karena nilai VIF semua variabel independen lebih kecil dari 10. 
Tri Harsini Wahyuningsih : Intensi Kewirausahaan Mahasiswa (Studi Perbandingan Antara Mahasiswa PTS Dan PTN)

\section{Uji Heteroskedastisitas}

Uji heteroskedastisitas bertujuan untuk menguji apakah dalam model regresi terjadi ketidaksamaan variance dari residual satu pengamatan ke pengamatan yang lain. Model regresi yang baik adalah model yang tidak terjadi heteroskedastisitas. Penelitian ini menggunakan uji Glejser untuk mendeteksi ada atau tidaknya heteroskedastisitas. Apabila probabilitas signifikansi diatas tingkat kepercayaan 5\%, berarti tidak terdapat heteroskedastisitas. Berdasarkan hasil pengolahan data didapatkan temuan bahwa nilai sign. untuk semua variabel independen diatas 5\%. Dengan demikian tidak terjadi heteroskedastisitas dalam model regresi ini.

\section{Uji Normalitas}

Uji normalitas bertujuan untuk menguji apakah dalam model regresi, variabel pengganggu atau residual memiliki distribusi normal ataukah tidak. Penggunaan uji $t$ mengasumsikan bahwa nilai residual mengikuti distribusi normal. Berdasarkan analisis grafik, output histogram dan penyebaran titik-titik di sekitar garis diagonalnya mengikuti arah garis diagonal, sehingga mengindikasikan bahwa model regresi memenuhi asumsi normalitas.

\section{Uji Hipotesis}

Setelah dipastikan tidak ada masalah pada instrumen penelitian, baik dari uji validitas dan reliabilitas, serta uji asumsi maka dilakukan uji hipotesis. Analisis data untuk menguji hipotesis adalah seperti berikut:

\section{Analisis regresi berganda dan uji t}

Analisis regresi berganda bertujuan untuk mengetahui arah hubungan antara variabel independen dengan variabel dependen, sedangkan uji t digunakan untuk mengetahui ada tidaknya pengaruh variabel independen terhadap variabel dependen. Untuk mahasiswa yang kuliah di perguruan tinggi swasta, hasil pengolahan data seperti disajikan dalam tabel 2 sehingga dapat disusun model persamaan regresi berikut:

$$
Y=5,623-0,074 X_{1}+0,310 X_{2}+0,118 X_{3}+e
$$

Tabel 2. Hasil Analisis Regresi Berganda Untuk Mahasiswa yang kuliah di PTS

\begin{tabular}{|c|c|c|c|c|c|c|}
\hline \multicolumn{7}{|c|}{ Coefficients $^{\mathbf{a}}$} \\
\hline & \multirow[t]{2}{*}{ Model } & \multicolumn{2}{|c|}{$\begin{array}{l}\text { Unstandardized } \\
\text { Coefficients }\end{array}$} & \multirow{2}{*}{$\begin{array}{l}\text { Standardized } \\
\text { Coefficients } \\
\text { Beta }\end{array}$} & \multirow[t]{2}{*}{$\mathrm{t}$} & \multirow[t]{2}{*}{ Sig. } \\
\hline & & $\mathrm{B}$ & Std. Error & & & \\
\hline \multirow[t]{4}{*}{1} & (Constant) & 5,623 & 1,289 & & 4,363 & 000 \\
\hline & Prestasi_pts &,- 074 & ,072 &,- 075 & $-1,032$ & ,303 \\
\hline & Efikasi_pts & ,310 & ,097 & ,270 & 3,197 & ,002 \\
\hline & $\begin{array}{l}\text { Instrumentasi } \\
\text { pts }\end{array}$ & ,118 & ,068 & 145 & 1,722 & ,087 \\
\hline
\end{tabular}

Tabel 3 memperlihatkan hasil analisis regresi berganda dan uji $t$ untuk mahasiswa yang kuliah di PTN. Berdasarkan tabel tersebut dapat dibuat model persamaan regresi seperti berikut:

$$
\mathrm{Y}=2,739+0,005 \mathrm{X}_{1}+0,390 \mathrm{X}_{2}+0,172 \mathrm{X}_{3}+\mathrm{e}
$$


Tabel 3. Hasil Analisis Regresi Berganda Untuk Mahasiswa yang kuliah di PTN

\begin{tabular}{|c|c|c|c|c|c|c|}
\hline \multicolumn{7}{|c|}{ Coefficients $^{\mathrm{a}}$} \\
\hline & \multirow[t]{2}{*}{ Model } & \multicolumn{2}{|c|}{$\begin{array}{l}\text { Unstandardized } \\
\text { Coefficients }\end{array}$} & \multirow{2}{*}{$\begin{array}{c}\begin{array}{c}\text { Standardized } \\
\text { Coefficients }\end{array} \\
\text { Beta }\end{array}$} & \multirow[t]{2}{*}{$\mathrm{t}$} & \multirow[t]{2}{*}{ Sig. } \\
\hline & & $\mathrm{B}$ & Std. Error & & & \\
\hline \multirow{4}{*}{1} & (Constant) & 2,739 & ,926 & & 2,959 &, 003 \\
\hline & Prestasi_ptn &, 005 &, 054 &, 005 & ,084 & ,933 \\
\hline & Efikasi_ptn & ,390 &, 081 & ,318 & 4,814 &, 000 \\
\hline & Instrumentasi_ptn & 172 &, 061 & 186 & 2,802 &, 005 \\
\hline
\end{tabular}

Berdasarkan kedua tabel diatas, ternyata kebutuhan akan prestasi tidak berpengaruh terhadap intensi kewirausahaan mahasiswa, karena nilai signifikansinya lebih besar dari 5\%. Temuan ini sejalan dengan hasil penelitian Indarti (2008), Sarwoko (2011), dan Vilathuvahna (2015). Ukuran-ukuran prestasi lebih mengedepankan keberhasilan bekerja di perusahaan, bukan keberhasilan berwirausaha. Dengan demikian hipotesis 1 yang menyatakan bahwa kebutuhan akan prestasi berpengaruh positif terhadap intensi kewirausahaan mahasiswa, tidak terbukti, baik untuk mahasiswa PTS maupun PTN.

Efikasi diri terbukti mempengaruhi intensi kewirausahaan mahasiswa, baik untuk mahasiswa PTS maupun PTN. Semakin tinggi kepercayaan diri seorang mahasiswa atas kemampuan dirinya untuk dapat berusaha, maka semakin besar pula keinginannya untuk menjadi seorang wirausaha. Temuan ini sejalan dengan penelitian Indarti (2008); Sudarusman (2011), Sarwoko (2011), Endratno (2014), Herawati (2015), dan Vilathuvahna (2015). Hal ini juga membuktikan diterimanya hipotesis 2, yang menyatakan bahwa efikasi diri berpengaruh positif terhadap intensi kewirausahaan mahasiswa.

Hasil pengujian hipotesis menunjukkan bahwa kesiapan instrumentasi berpengaruh positif dan signifikan hanya pada mahasiswa PTN saja. Hal itu berarti, semakin baik kesiapan instrumentasi yang meliputi ketersediaan modal, jaringan sosial, dan kemudahan akses pada informasi, maka akan semakin kuat keinginan mahasiswa untuk menjadi seorang wirausahawan. Namun demikian, pengaruh kesiapan instrumentasi terhadap intensi kewirausahaan tidaklah signifikan untuk mahasiswa yang kuliah di perguruan tinggi swasta. Dengan demikian, hipotesis 3 hanya terbukti untuk mahasiswa PTN saja.

Tanpa membedakan mahasiswa PTS atau PTN, kebutuhan akan prestasi juga tidak berpengaruh terhadap intensi kewirausahaan mahasiswa, sedangkan efikasi diri dan kesiapan instrumentasi berpengaruh positif signifikan terhadap intensi kewirausahaan mahasiswa (tabel 4).

Tabel 4. Hasil Analisis Regresi Berganda

\begin{tabular}{|c|c|c|c|c|c|c|}
\hline \multicolumn{7}{|c|}{ Coefficients $^{\mathbf{a}}$} \\
\hline & \multirow[t]{2}{*}{ Model } & \multicolumn{2}{|c|}{$\begin{array}{l}\text { Unstandardized } \\
\text { Coefficients }\end{array}$} & \multirow{2}{*}{$\begin{array}{c}\begin{array}{c}\text { Standardized } \\
\text { Coefficients }\end{array} \\
\text { Beta }\end{array}$} & \multirow[t]{2}{*}{$\mathrm{t}$} & \multirow[t]{2}{*}{ Sig. } \\
\hline & & $\mathrm{B}$ & Std. Error & & & \\
\hline \multirow{4}{*}{1} & (Constant) & 3,415 &, 747 & & 4,570 &, 000 \\
\hline & Prestasi &,- 012 & 043 &,- 013 &,- 289 & ,772 \\
\hline & Efikasi & ,376 &, 062 & ,313 & 6,038 &, 000 \\
\hline & Instrumentasi & ,158 &, 046 & ,179 & 3,450 &, 001 \\
\hline
\end{tabular}

a. Dependent Variable: Intensi 
Tri Harsini Wahyuningsih : Intensi Kewirausahaan Mahasiswa (Studi Perbandingan Antara Mahasiswa PTS Dan PTN)

\section{Compare Means}

Untuk menguji hipotesis 4 sampai dengan hipotesis 8, dilakukan uji compare means dengan independent-samples $T$ test. Tabel 5 memperlihatkan bahwa rata-rata mahasiswa laki-laki adalah 8,0674 dan perempuan 7,6977. Berdasarkan temuan tersebut, untuk mahasiswa yang berasal dari perguruan tinggi swasta, intensi kewirausahaan mahasiswa lakilaki lebih tinggi daripada perempuan. Hasil berbeda ditunjukkan untuk mahasiswa yang berasal dari perguruan tinggi negeri. Pada tabel 6 dapat dilihat bahwa rata-rata mahasiswa laki-laki adalah 7,0707 dan perempuan 7,3032. Temuan tersebut menunjukkan bahwa intensi kewirausahaan mahasiswa perempuan lebih tinggi daripada laki-laki. Dengan demikian hipotesis 4 yang menyatakan laki-laki memiliki intensi kewirausahaan lebih tinggi daripada perempuan, terbukti, untuk responden yang berasal dari perguruan tinggi swasta. Tanpa membedakan PTS atau PTN, diketemukan juga bahwa intensi kewirausahaan mahasiswa laki-laki lebih tinggi daripada perempuan (tabel 7).

Tabel 5. Hasil Compare Means Responden PTS Berdasar Jenis Kelamin

\begin{tabular}{llcccc}
\hline \multicolumn{7}{c}{ Group Statistics } \\
\hline & \multirow{2}{*}{ Jenis_kelamin } & $\mathrm{N}$ & Mean & $\begin{array}{c}\text { Std. } \\
\text { Deviation }\end{array}$ & $\begin{array}{c}\text { Std. Error } \\
\text { Mean }\end{array}$ \\
\hline \multirow{2}{*}{ Intensi_pts dimension1 Laki-laki } & 89 & 8,0674 & 1,50603 &, 15964 \\
& Perempuan & 86 & 7,6977 & 1,60198 &, 17275 \\
\hline
\end{tabular}

Tabel 6. Hasil Compare Means Responden PTN Berdasar Jenis Kelamin

\begin{tabular}{|c|c|c|c|c|c|c|}
\hline \multicolumn{7}{|c|}{ Group Statistics } \\
\hline & Jenis_ & relamin & $\mathrm{N}$ & Mean & $\begin{array}{c}\text { Std. } \\
\text { Deviation }\end{array}$ & $\begin{array}{c}\text { Std. Error } \\
\text { Mean }\end{array}$ \\
\hline \multirow{2}{*}{ Intensi_ptn } & \multirow{2}{*}{ dimension 1} & Laki-laki & 99 & 7,0707 & 1,93914 & ,19489 \\
\hline & & Perempuan & 155 & 7,3032 & 1,69940 &, 13650 \\
\hline
\end{tabular}

Tabel 7. Hasil Compare Means Responden Berdasar Jenis Kelamin

\begin{tabular}{|c|c|c|c|c|c|c|}
\hline \multicolumn{7}{|c|}{ Group Statistics } \\
\hline & Jenis & elamin & $\mathrm{N}$ & Mean & $\begin{array}{c}\text { Std. } \\
\text { Deviation }\end{array}$ & $\begin{array}{c}\text { Std. Error } \\
\text { Mean }\end{array}$ \\
\hline \multirow{2}{*}{ Intensi } & \multirow{2}{*}{ dimension 1} & Laki-laki & 188 & 7,5426 & 1,81299 &, 13223 \\
\hline & & Perempuan & 241 & 7,4440 & 1,67269 & 10775 \\
\hline
\end{tabular}

Hipotesis 5 yang menyatakan mahasiswa yang berusia muda memiliki intensi kewirausahaan lebih tinggi daripada mahasiswa berusia tua, terbukti, untuk responden yang kuliah di perguruan tinggi negeri. Hal ini didasarkan pada perbandingan antara tabel 8 dan tabel 9. Tabel 8 memperlihatkan bahwa rata-rata mahasiswa PTS yang berusia kurang dari 20 tahun adalah 7,8396 dan berusia 20 tahun ke atas adalah 7,9565. Berdasarkan temuan tersebut, untuk mahasiswa yang berasal dari perguruan tinggi swasta, intensi kewirausahaan mahasiswa yang berusia 20 tahun keatas (tua) lebih tinggi daripada yang berusia kurang dari 20 tahun (muda). Hasil berbeda ditunjukkan untuk mahasiswa yang berasal dari perguruan tinggi negeri. Pada tabel 9 dapat dilihat bahwa rata-rata mahasiswa yang berusia kurang dari 20 tahun adalah 7,2296 dan berusia 20 tahun keatas 7,1933. Temuan tersebut menunjukkan bahwa intensi kewirausahaan mahasiswa yang berusia muda lebih tinggi daripada yang berusia tua. Tanpa membedakan PTS atau PTN, diketemukan bahwa intensi kewirausahaan 
mahasiswa berusia muda lebih tinggi daripada mahasiswa berusia tua (tabel 10). Dengan demikian hipotesis 5 mendapatkan dukungan.

Tabel 8. Hasil Compare Means Responden PTS Berdasar Usia

\begin{tabular}{llcccc}
\hline \multicolumn{5}{c}{ Group Statistics } & \\
\hline & $\mathrm{N}$ & Mean & $\begin{array}{c}\text { Std. } \\
\text { Deviation }\end{array}$ & $\begin{array}{c}\text { Std. Error } \\
\text { Mean }\end{array}$ \\
\hline Intensi_pts & $\begin{array}{l}\text { kurang dari 20 } \\
\text { tahun }\end{array}$ & 106 & 7,8396 & 1,47446 &, 14321 \\
& 20 tahun keatas & 69 & 7,9565 & 1,69285 &, 20379 \\
\hline
\end{tabular}

Tabel 9. Hasil Compare Means Responden PTN Berdasar Usia

\begin{tabular}{|c|c|c|c|c|c|}
\hline \multicolumn{6}{|c|}{ Group Statistics } \\
\hline & Usia & $\mathrm{N}$ & Mean & $\begin{array}{c}\text { Std. } \\
\text { Deviation }\end{array}$ & $\begin{array}{l}\text { Std. Error } \\
\text { Mean }\end{array}$ \\
\hline \multirow[t]{2}{*}{ Intensi_ptn } & $\begin{array}{l}\text { kurang dari } 20 \\
\text { tahun }\end{array}$ & 135 & 7,2296 & 1,70136 & , 14643 \\
\hline & 20 tahun ke atas & 119 & 7,1933 & 1,90573 &, 17470 \\
\hline
\end{tabular}

Tabel 10. Hasil Compare Means Responden Berdasar Usia

\begin{tabular}{llcccc}
\hline \multicolumn{5}{c}{ Group Statistics } \\
\hline Usia & $\mathrm{N}$ & Mean & $\begin{array}{c}\text { Std. } \\
\text { Deviation }\end{array}$ & $\begin{array}{c}\text { Std. Error } \\
\text { Mean }\end{array}$ \\
\hline Intensi & $\begin{array}{l}\text { kurang dari } 20 \\
\text { tahun }\end{array}$ & 241 & 7,4979 & 1,63076 &, 10505 \\
& 20 tahun keatas & 188 & 7,4734 & 1,86276 &, 13586 \\
\hline
\end{tabular}

Penelitian ini juga ingin mengetahui apakah ada perbedaan intensi kewirausahaan antara mahasiswa yang berlatarbelakang pendidikan ekonomi dan mahasiswa yang berlatarbelakang pendidikan non-ekonomi. Untuk mahasiswa yang kuliah di perguruan tinggi swasta, didapatkan bahwa mean mahasiswa yang berlatarbelakang pendidikan ekonomi adalah 7,8938 dan non-ekonomi 7,8710, seperti terlihat di tabel 11. Untuk mahasiswa yang kuliah di perguruan tinggi negeri, didapatkan bahwa mean mahasiswa yang berlatarbelakang pendidikan ekonomi adalah 7,6800 dan non-ekonomi 7,1616, seperti terlihat di tabel 12 . Tanpa membedakan PTS atau PTN, diketemukan bahwa intensi kewirausahaan mahasiswa yang berlatarbelakang pendidikan ekonomi lebih tinggi daripada mahasiswa yang berpendidikan non ekonomi (tabel 13). Dengan demikian hipotesis 6 yang menyatakan bahwa mahasiswa yang berlatarbelakang pendidikan ekonomi dan bisnis memiliki intensi kewirausahaan lebih tinggi daripada mahasiswa yang berlatarbelakang pendidikan nonekonomi dan bisnis, terbukti.

Tabel 11. Hasil Compare Means Responden PTS Berdasar Latarbelakang Pendidikan

\begin{tabular}{llcccc}
\hline \multicolumn{5}{c}{ Group Statistics } \\
\hline & Fakultas & $\mathrm{N}$ & Mean & $\begin{array}{c}\text { Std. } \\
\text { Deviation }\end{array}$ & $\begin{array}{c}\text { Std. Error } \\
\text { Mean }\end{array}$ \\
\hline Intensi_pts & Ekonomi & 113 & 7,8938 & 1,54320 &, 14517 \\
& Non ekonomi & 62 & 7,8710 & 1,60413 &, 20373 \\
\hline
\end{tabular}


Tri Harsini Wahyuningsih : Intensi Kewirausahaan Mahasiswa (Studi Perbandingan Antara Mahasiswa PTS Dan PTN)

Tabel 12. Hasil Compare Means Responden PTN Berdasar Latarbelakang Pendidikan

\begin{tabular}{llcccc}
\hline \multicolumn{5}{c}{ Group Statistics } & \\
\hline & Fakultas & $\mathrm{N}$ & Mean & Std. Deviation & $\begin{array}{c}\text { Std. Error } \\
\text { Mean }\end{array}$ \\
\hline Intensi_ptn & Ekonomi & 25 & 7,6800 & 1,79629 &, 35926 \\
& Non-ekonomi & 229 & 7,1616 & 1,79304 &, 11849 \\
\hline
\end{tabular}

Tabel 13. Hasil Compare Means Responden Berdasar Latarbelakang Pendidikan

\begin{tabular}{llcccc}
\hline \multicolumn{5}{c}{ Group Statistics } & \\
\hline & Fakultas & $\mathrm{N}$ & Mean & $\begin{array}{c}\text { Std. } \\
\text { Deviation }\end{array}$ & $\begin{array}{c}\text { Std. Error } \\
\text { Mean }\end{array}$ \\
\hline Intensi & Ekonomi & 138 & 7,8551 & 1,58713 &, 13511 \\
& Non ekonomi & 291 & 7,3127 & 1,77584 &, 10410 \\
\hline
\end{tabular}

Hipotesis 7 menyatakan bahwa mahasiswa yang mempunyai pengalaman kerja memiliki intensi kewirausahaan lebih tinggi daripada mahasiswa yang tidak mempunyai pengalaman kerja. Hipotesis ini juga mendapatkan dukungan, berdasarkan temuan yang ditampilkan oleh tabel 14, tabel 15 , dan tabel 16. Untuk mahasiswa yang kuliah di perguruan tinggi swasta (tabel 14), nilai rata-rata mahasiswa yang mempunyai pengalaman bekerja sebesar 8,1481 dan mahasiswa yang tidak memiliki pengalaman kerja sebesar 7,7686. Untuk mahasiswa yang kuliah di perguruan tinggi negeri (tabel 15), nilai rata-rata mahasiswa yang mempunyai pengalaman bekerja sebesar 7,6234 dan mahasiswa yang tidak memiliki pengalaman kerja sebesar 7,0339. Tanpa membedakan PTS atau PTN, nilai rata-rata mahasiswa yang mempunyai pengalaman bekerja sebesar 7,8397 dan mahasiswa yang tidak memiliki pengalaman kerja sebesar 7,3322, seperti terlihat pada tabel 16. Semua temuan tersebut mendukung hipotesis 7 yang menyatakan bahwa mahasiswa yang mempunyai pengalaman kerja memiliki intensi kewirausahaan lebih tinggi daripada mahasiswa yang tidak mempunyai pengalaman kerja.

Tabel 14. Hasil Compare Means Responden PTS Berdasar Pengalaman Kerja

\begin{tabular}{llcccc}
\hline & \multicolumn{5}{c}{ Group Statistics } \\
\hline Pengalaman & $\mathrm{N}$ & Mean & $\begin{array}{c}\text { Std. } \\
\text { Deviation }\end{array}$ & $\begin{array}{c}\text { Std. Error } \\
\text { Mean }\end{array}$ \\
\hline Intensi_pts & Pernah & 54 & 8,1481 & 1,55900 &, 21215 \\
& Tidak pernah & 121 & 7,7686 & 1,55328 &, 14121 \\
\hline
\end{tabular}

Tabel 15. Hasil Compare Means Responden PTN Berdasar Pengalaman Kerja

\begin{tabular}{llcccc}
\hline \multicolumn{5}{c}{ Group Statistics } & \\
\hline & Pengalaman & $\mathrm{N}$ & Mean & $\begin{array}{c}\text { Std. } \\
\text { Deviation }\end{array}$ & $\begin{array}{c}\text { Std. Error } \\
\text { Mean }\end{array}$ \\
\hline Intensi_ptn & Pernah & 77 & 7,6234 & 1,84276 &, 21000 \\
& Tidak pernah & 177 & 7,0339 & 1,75129 &, 13164 \\
\hline
\end{tabular}


Tabel 16. Hasil Compare Means Responden Berdasar Pengalaman Kerja

\begin{tabular}{llcccc}
\hline \multicolumn{5}{c}{ Group Statistics } & \\
\hline & Pengalaman & $\mathrm{N}$ & Mean & $\begin{array}{c}\text { Std. } \\
\text { Deviation }\end{array}$ & $\begin{array}{c}\text { Std. Error } \\
\text { Mean }\end{array}$ \\
\hline Intensi & Pernah & 131 & 7,8397 & 1,74452 &, 15242 \\
& Tidak pernah & 298 & 7,3322 & 1,70966 &, 09904 \\
\hline
\end{tabular}

Latar belakang keluarga/orangtua merupakan faktor demografis lain yang diteliti selain jenis kelamin, usia, latar belakang pendidikan, dan pengalaman bekerja. Untuk mahasiswa yang kuliah di perguruan tinggi swasta (tabel 17), nilai rata-rata mahasiswa yang orangtuanya wirausaha sebesar 8,2794 dan mahasiswa yang orangtuanya non-wirausaha sebesar 7,6355. Untuk mahasiswa yang kuliah di perguruan tinggi negeri (tabel 18), nilai rata-rata mahasiswa yang orangtuanya wirausaha sebesar 7,4500 dan mahasiswa yang orangtuanya non-wirausaha sebesar 7,1034. Tanpa membedakan PTS atau PTN, nilai ratarata mahasiswa yang orangtuanya wirausaha sebesar 7,8311 dan mahasiswa yang orangtuanya non-wirausaha sebesar 7,3060 seperti terlihat pada tabel 19. Semua temuan tersebut mendukung hipotesis 8 yang menyatakan bahwa Mahasiswa yang orangtuanya pebisnis memiliki intensi kewirausahaan lebih tinggi daripada mahasiswa yang orangtuanya bukan pebisnis.

Tabel 17. Hasil Compare Means Responden PTS Berdasar Latarbelakang Orangtua

\begin{tabular}{llcccc}
\hline \multicolumn{5}{c}{ Group Statistics } & \\
\hline & Orangtua & $\mathrm{N}$ & Mean & $\begin{array}{c}\text { Std. } \\
\text { Deviation }\end{array}$ & $\begin{array}{c}\text { Std. Error } \\
\text { Mean }\end{array}$ \\
\hline Intensi_pts & Wirausaha & 68 & 8,2794 & 1,45423 &, 17635 \\
& Non-wirausaha & 107 & 7,6355 & 1,58050 &, 15279 \\
\hline
\end{tabular}

Tabel 18. Hasil Compare Means Responden PTN Berdasar Latarbelakang Orangtua Group Statistics

\begin{tabular}{llcccc}
\hline & Orangtua & $\mathrm{N}$ & Mean & $\begin{array}{c}\text { Std. } \\
\text { Deviation }\end{array}$ & $\begin{array}{c}\text { Std. Error } \\
\text { Mean }\end{array}$ \\
\hline Intensi_ptn & Wirausaha & 80 & 7,4500 & 1,64509 &, 18393 \\
& Non-wirausaha & 174 & 7,1034 & 1,85631 &, 14073 \\
\hline
\end{tabular}

Tabel 19. Hasil Compare Means Responden Berdasar Latarbelakang Orangtua

\begin{tabular}{llcccc}
\hline \multicolumn{5}{c}{ Group Statistics } & \\
\hline & Orangtua & $\mathrm{N}$ & Mean & $\begin{array}{c}\text { Std. } \\
\text { Deviation }\end{array}$ & $\begin{array}{c}\text { Std. Error } \\
\text { Mean }\end{array}$ \\
\hline Intensi & Wirausaha & 148 & 7,8311 & 1,60945 &, 13230 \\
& Non-wirausaha & 281 & 7,3060 & 1,77249 &, 10574 \\
\hline
\end{tabular}

Oleh karena populasi dalam penelitian ini dibedakan menjadi dua kelompok, maka perlu diketahui juga intensi kewirausahaan untuk mahasiswa yang kuliah di perguruan tinggi swasta dan perguruan tinggi negeri. Tabel 20 menunjukkan bahwa nilai rata-rata mahasiswa yang kuliah di perguruan tinggi swasta sebesar 7,8857 dan mahasiswa yang kuliah di perguruan tinggi negeri sebesar 7,2126. Dengan demikian diketemukan bahwa intensi kewirausahaan mahasiswa PTS lebih tinggi dibandingkan mahasiswa PTN. 
Tri Harsini Wahyuningsih : Intensi Kewirausahaan Mahasiswa (Studi Perbandingan Antara Mahasiswa PTS Dan PTN)

Tabel 20. Hasil Compare Means Responden Berdasar Asal Perguruan Tinggi

\begin{tabular}{llcccc}
\hline \multicolumn{6}{c}{ Group Statistics } \\
\hline \multirow{2}{*}{ Kampus } & & $\mathrm{N}$ & Mean & $\begin{array}{c}\text { Std. } \\
\text { Deviation }\end{array}$ & $\begin{array}{c}\text { Std. Error } \\
\text { Mean }\end{array}$ \\
\hline \multirow{2}{*}{ Intensi dimension1 } & PTS & 175 & 7,8857 & 1,56049 &, 11796 \\
& PTN & 254 & 7,2126 & 1,79648 &, 11272 \\
\hline
\end{tabular}

\section{KESIMPULAN}

Sesuai dengan tujuan penelitian maka dapat diambil kesimpulan seperti berikut:

a. Kebutuhan akan prestasi tidak berpengaruh terhadap intensi kewirausahaan mahasiswa, baik untuk mahasiswa yang kuliah di PTS maupun PTN.

b. Efikasi diri berpengaruh positif terhadap intensi kewirausahaan mahasiswa, baik untuk mahasiswa yang kuliah di PTS maupun PTN. Variabel ini terbukti sebagai faktor yang paling dominan mempengaruhi intensi kewirausahaan mahasiswa perguruan tinggi swasta maupun mahasiswa perguruan tinggi negeri.

c. Kesiapan instrumentasi berpengaruh positif terhadap intensi kewirausahaan mahasiswa PTN, namun tidak berpengaruh bagi mahasiswa PTS.

d. Tanpa membedakan asal PT, kebutuhan akan prestasi juga tidak berpengaruh terhadap intensi kewirausahaan mahasiswa, sedangkan efikasi diri dan kesiapan instrumentasi berpengaruh positif signifikan terhadap intensi kewirausahaan mahasiswa

e. Faktor demografis yang terdiri dari jenis kelamin, usia, latarbelakang pendidikan, pengalaman bekerja, dan latarbelakang orangtua juga digunakan untuk mengetahui pengaruhnya terhadap intensi kewirausahaan mahasiswa.

1. Untuk mahasiswa PTS, intensi kewirausahaan mahasiswa laki-laki lebih tinggi dibandingkan perempuan. Temuan sebaliknya untuk mahasiswa PTN, perempuan memiliki intensi kewirausahaan lebih tinggi daripada laki-laki. Tanpa membedakan asal PT, ternyata mahasiswa laki-laki memiliki intensi kewirausahaan lebih tinggi daripada perempuan.

2. Untuk mahasiswa PTS, diketemukan bahwa mahasiswa yang berusia tua memiliki intensi kewirausahaan lebih tinggi daripada mahasiswa berusia muda. Namun untuk mahasiswa PTN, mahasiswa yang berusia muda memiliki intensi kewirausahaan lebih tinggi daripada mahasiswa berusia tua. Temuan ini samadengan temuan tanpa membedakan asal PT.

3. Mahasiswa yang berlatarbelakang pendidikan ekonomi dan bisnis memiliki intensi kewirausahaan lebih tinggi daripada mahasiswa yang berlatarbelakang pendidikan non-ekonomi dan bisnis, baik bagi mahasiswa PTS maupun mahasiswa PTN.

4. Mahasiswa yang mempunyai pengalaman kerja memiliki intensi kewirausahaan lebih tinggi daripada mahasiswa yang tidak mempunyai pengalaman kerja, baik untuk mahasiswa PTS maupun mahasiswa PTN.

5. Mahasiswa yang orangtuanya pebisnis memiliki intensi kewirausahaan lebih tinggi daripada mahasiswa yang orangtuanya bukan pebisnis, baik untuk mahasiswa PTS maupun mahasiswa PTN.

f. Penelitian ini juga mendapatkan temuan bahwa mahasiswa yang kuliah di perguruan tinggi swasta memiliki intensi kewirausahaan lebih tinggi daripada mahasiswa yang kuliah di perguruan tinggi negeri. 


\section{DAFTAR PUSTAKA}

Alma, Buchari. 2013. Kewirausahaan Untuk Mahasiswa dan Umum. Bandung: Penerbit Alfabeta.

Endratno, Hermin dan Hengky Widhiandono. 2014. Intensi Kewirausahaan Mahasiswa (Studi Perbandingan Antara Mahasiswa FE UMP dan FE Unsoed). Sustainable Competitive Advantage. 4 (1). www.jp.feb.unsoed.ac.id

Ghozali, Imam. 2013. Aplikasi Analisis Multivariate Dengan Program IBM SPSS21 Update PLS Regresi. Edisi 7. Semarang: Badan Penerbit Universitas Diponegoro.

Herawati, Nurul dan Yudhanta Sambharakreshna. 2015. Faktor Apakah yang Mempengaruhi Intensi Kewirausahaan Mahasiswa Akuntansi?. Prosiding Seminar Nasional $4^{\text {th }}$ UNS SME's Summit \& Awards 2015. http://psp-kumkm.lppm.uns.ac.id/files/2016/01/nurulherawati-prosiding-sme-s-combinedpdf 1.pdf

Indarti, Nurul dan Rokhima Rostiani. 2008. Intensi Kewirausahaan Mahasiswa: Studi Perbandingan Antara Indonesia, Jepang dan Norwegia. Jurnal Ekonomika dan Bisnis Indonesia. 23 (4).

Sarwoko, Endi. 2011. Kajian Empiris Entrepreneur Intention Mahasiswa. Jurnal Ekonomi Bisnis. 16 (2) .

Sata, Mesay. 2013. Entrepreneurial Intention Among Undergraduate Business Student. International Journal of Research in Management, Economics and Commerce. 3 (9).

Sudarusman, Eka. 2011. Intensi Kewirausahaan Mahasiswa: Studi Kasus pada Mahasiswa STIM YKPN Yogyakarta. Jurnal Telaah Bisnis. 12 (1).

Suryana. 2006. Kewirausahaan: Pedoman Praktis Kiat dan Proses Menuju Sukses. Jakarta: Penerbit Salemba Empat.

Vilathuvahna, Ananda Ahda dan Taufik R D A Nugroho. 2015. Intensi Kewirausahaan Mahasiswa Universitas Trunojoyo Madura. Jurnal Agriekonomika. 4 (1).

Widarjono, Agus. 2010. Analisis Statistika Multivariat Terapan. Yogyakarta: Unit Penerbitan dan Percetakan STIM YKPN.

Wijaya, Toni. 2012. Cepat Menguasai SPSS 20 Untuk Olah dan Interpretasi Data. Yogyakarta: Cahaya Atma Pustaka.

Wiyono, Gendro. 2011. Merancang Penelitian Bisnis dengan Alat Analisis SPSS dan SmartPLS. Yogyakarta: Unit Penerbitan dan Percetakan STIM YKPN . 2015. Keadaan Ketenagakerjaan Agustus 2015. Berita Resmi Statistik No. 103/11/Th. XVIII, 5 November 2015. https://www.bps.go.id/index.php/Brs 